\title{
Evaluación de la influencia de la rugosidad superficial sobre la colonización epilítica de calizas mediante técnicas sin contacto
}

\section{Assessing the influence of surface roughness on the epilithic colonisation of limestones by non-contact techniques}

\author{
A. Z. Miller(*), M. A. Rogerio-Candelera(**), A. Dionísio(*), M. F. Macedo(***), C. Saiz-Jiménez ${ }^{(* *)}$
}

Recepción/Received: 26-XI-10

Aceptación/Accepted: 24-II-11

\section{RESUMEN}

La colonización de la piedra por microorganismos ha generado una extensa literatura sobre los mecanismos y tasas de degradación fisicoquímica de las superficies pétreas, tanto en laboratorio como en estudios de campo. La colonización biológica de piedra de construcción depende de parámetros intrínsecos como son su composición mineral, textura, porosidad y permeabilidad, así como de parámetros ambientales. Este estudio demuestra la relación entre la rugosidad superficial de la piedra y la colonización epilítica, cuantificada en tres tipos de caliza mediante técnicas no destructivas: medida de la rugosidad superficial usando un perfilómetro óptico y análisis digital de imágenes. De acuerdo con la rugosidad media aritmética $\left(R_{a}\right)$ y la amplitud media de rugosidad $\left(R_{z}\right)$, determinadas para la caliza de Ançã, la caliza de Lioz y la piedra de Lecce, puede concluirse que las piedras con alta rugosidad superficial son más propensas a la colonización microbiana.

Palabras clave: piedra, rugosidad superficial, colonización epilítica, técnicas no destructivas.

\section{SUMMARY}

The importance of stone colonisation by microorganisms has led to an extensive literature on mechanisms and rates of physicochemical degradation of stone surface, both in laboratory and field contexts. Biological colonisation of a stone surface depends on intrinsic stone parameters like mineral composition, texture, porosity, and permeability, as well as on environmental parameters. In the present study, quantification of stone surface roughness and its relationship to epilithic colonisation was demonstrated for three types of limestones throughout non-destructive techniques, namely optical surface roughness instrument and digital image analysis. According to the roughness average $\left(R_{a}\right)$ and mean roughness depth $\left(R_{z}\right)$ determined for Ançã limestone, Lioz limestone and Lecce stone, it can be concluded that great surface roughness stones render them prone to microbial colonisation.

Keywords: stone, surface roughness, ephilitic colonisation, non-destructive techniques.

(*) Instituto Superior Técnico (Lisboa, Portugal).

(**) Instituto de Recursos Naturales y Agrobiología de Sevilla, CSIC (Sevilla, España).

(***) Universidade Nova de Lisboa (Caparica, Portugal). 


\section{INTRODUCCIÓN}

El deterioro del patrimonio arquitectónico puede ser el paradigma de un complejo proceso influenciado por las propiedades intrínsecas de los materiales pétreos (composición mineral, textura, porosidad, etc.) y por factores extrínsecos como las condiciones climáticas, los daños producidos por las técnicas de construcción y por la colonización biológica. Los microorganismos (bacterias, cianobacterias, algas, hongos y líquenes) inducen cambios estéticos, físicos y químicos en los substratos. Varios factores influencian su colonización, crecimiento, distribución y actividad metabólica sobre los monumentos pétreos, incluyendo: 1) la bio-receceptividad de los substratos $(1)$; 2) los parámetros ambientales (radiación solar, temperatura, régimen hídrico, viento, contaminación atmosférica, etc.), y 3) parámetros microclimáticos específicos (orientación, exposición a la sombra, humedecimiento constante por capilaridad, etc.). Parece claro que la disponibilidad de agua es uno de los factores más importantes puesto que todos los organismos la necesitan para su metabolismo $(2,3)$. No obstante, la rugosidad superficial, definida como la medida de las irregularidades de una superficie, juega también un importante papel en el desarrollo de la colonización microbiana. Guillitte y Dreesen (4), Silva et al. (5), Tomaselli et al. (6) y Prieto y Silva $(7,9)$ han demostrado la importancia de la rugosidad superficial en la bio-receptividad de las piedras, mostrando que diferentes acabados superficiales tienen un efecto significativo sobre la extensión o la intensidad de la colonización microbiana, siendo las superficies pétreas rugosas más bio-receptivas que las superficies pulidas (7). Las piedras con grandes cavidades superficiales pueden ofrecer mayores áreas para la colonización de células microbianas y para la retención de humedad en el material, generando condiciones microambientales apropiadas para el desarrollo de microorganismos. De hecho, la rugosidad superficial determina la adhesión, y la creación de micronichos que protegen a los microorganismos de las fuerzas hidrodinámicas y reducen la remoción de células (8). Además, la protección contra el viento y la radiación solar directa que brindan estos micronichos retiene agua y minimiza la evaporación (2). La adhesión de células y esporas a superficies con diferentes microtexturas ha sido estudiada por Scardino et al. $(8,9)$. Para varias especies de diatomeas, la adhesión se reduce en superficies con irregularidades menores que el tamaño de la célula, mientras que se incrementa sobre superficies lisas y cuando las texturas facilitan múltiples puntos de anclaje.

La cuantificación de la rugosidad superficial se ha usado para evaluar las condiciones de la piedra, los fenómenos de deterioro y su durabilidad $(10,11)$, así como para entender la adhesión de microorganismos (8) o para determinar la bio-receptividad de la piedra $(7,12,13)$. Del mismo modo, la rugosidad superficial puede usarse para

\section{INTRODUCTION}

The deterioration of stone architectural heritage can be a paradigm of a complex process influenced by the intrinsic properties of stone materials like mineral composition, texture, porosity, etc., and by extrinsic factors, such as climatic conditions, damage induced by building construction procedures, and biological colonisation. It is well recognised that aesthetical, physical and chemical changes are induced on lithic substrates by microorganisms, such as bacteria, cyanobacteria, algae, fungi and lichens. A number of factors influence their settlement, growth, distribution and metabolic activity on stone monuments, including: 1) bioreceptivity of the substrates (1); 2) environmental parameters (e.g. solar radiation, temperature, water regime, wind, atmospheric pollution, etc.), and 3) specific microclimatic parameters (e.g. orientation, exposure to shadow, permanent capillary humidity, etc.). Yet clearly, water availability is one of the most important factors since all organisms need water for their metabolism $(2,3)$. Nevertheless, the surface roughness, defined as the measure of the irregularities of a surface, also plays an important role in the development of microbial colonisation. Guillitte and Dreesen (4), Silva et al. (5), Tomaselli et al. (6) and Prieto and Silva (7) demonstrated the importance of surface roughness in the bioreceptivity of stones, reporting that different surface finishings have a significant effect on the extent or intensity of microbial colonisation; rougher stone surfaces are more bioreceptive than polished surfaces (7). Stones with large surface cavities may offer larger surface areas for the settlement of microbial cells and deep penetration of moisture into the material, providing appropriate microenvironmental conditions for the development of microorganisms. In fact, surface roughness determine microbial anchoring, such as adhesion, possibility of attachment points and microniches, which protect microorganisms from hydrodynamic forces and reduce cell removal (8). Moreover, protection against winds or direct sunshine offered by these microniches retains water and minimises evaporation (2). These microniches occur when the cell is smaller than the size of the pore (8). The attachment of cells and spores to surfaces with different microtextures was studied by Scardino et al. $(8,9)$. For several diatom species, attachment was reduced on surfaces with irregularities below the size of the cell, while attachment increased on smooth surfaces and when textures provided multiple numbers of attachment points.

The quantification of stone surface roughness has been used to assess stone surface conditions, deterioration phenomena and durability $(10,11)$, as well as to understand microorganisms attachment (8), or to determine stone bioreceptivity $(7,12,13)$. Furthermore, surface roughness can be used to quantify 
cuantificar patrones de meteorización fisicoquímica que pueden ser observables, o no, mediante microscopio óptico polarizado o electrónico. La rugosidad superficial se cuantifica a partir de las desviaciones verticales de una superficie con respecto a su forma regular ideal. Si estas desviaciones son grandes, la superficie es rugosa; si son pequeñas, la superficie es lisa. La rugosidad de una piedra de construcción está básicamente modelada por su acabado superficial, así como por otras características como el tamaño de grano, su textura superficial inherente, el tamaño y forma de los poros y su superficie específica.

Las técnicas de medición de la rugosidad superficial, también conocidas como perfilometría, pueden dividirse en dos amplias categorías: métodos con y sin contacto. Las medidas usuales de rugosidad superficial se hacen mediante un perfilómetro de aguja, que traza el perfil superficial con una aguja de diamante que se mueve a lo largo de la superficie de la muestra a una velocidad constante (14). Pueden calcularse varios valores medios derivados del perfil, como la rugosidad media aritmética $\left(R_{a}\right)$, la amplitud media de rugosidad $\left(R_{z}\right)$ y la rugosidad media cuadrática $\left(R_{q}\right)$. Los parámetros más comúnmente usados son $R_{a}$, que se define como el promedio aritmético de las desviaciones del perfil de rugosidad desde la línea central a lo largo de la longitud de medición (15), y $\mathrm{R}_{\mathrm{z}}$ el valor de la media aritmética de las distancias máximas pico-valle.

La técnica de la perfilometría de contacto fue diseñada originalmente para ensayos de metales desbastados o pulidos a máquina y suele llevarse a cabo en laboratorios. Sin embargo, se ha empleado igualmente en piedras obteniendo variados niveles de éxito $(15,16)$. Grissom et al. (15) encontraron dificultades para evaluar la rugosidad superficial de muestras macro-rugosas de caliza y arenisca debido al rango de medida del perfilómetro de aguja Surtronic 3+. El perfilómetro de aguja es un instrumento que obtiene la rugosidad superficial del contacto de algunos puntos sobre la aguja, y las dimensiones de la punta de la aguja puede impedirle alcanzar la base de los poros profundos. La textura de la piedra es bastante diferente de la de las superficies metálicas por lo que el rango de medida de la aguja no le permite medir los poros y agujeros profundos de la piedra, que generalmente están ausentes de las superficies metálicas. Por ello, para piedras rugosas y para aplicaciones in situ, las mediciones se ven limitadas.

Más recientemente, se han empleado perfilómetros ópticos sin necesidad de contacto basados en el principio de la interferometría óptica de doble haz (14). Varias técnicas sin contacto, como las basadas en láser y la perfilometría confocal se emplean ampliamente en la industria. La última técnica utiliza los principios de la microscopía confocal; el dispositivo se coloca perpendicular al objeto physicochemical weathering patterns that may or may not be observable under polarised optical or scanning electron microscopy. The surface roughness is quantified by the vertical deviations of a surface from its ideal regular form. If these deviations are large, the surface is rough; if they are small the surface is smooth. The roughness of a dimension stone is basically modelled by its surface finish, as well as by other features such as grain size, inherent surface texture, size and shape of the pores and specific surface area.

The surface roughness measuring techniques, also known as profilometry, can be divided into two broad categories: contact and non-contact methods. Common surface roughness measurements are made by a contact-type stylus profilometer, which trace the surface profile with a diamond stylus moved across the sample surface at a constant velocity (14). Various average values derived from the roughness profile are then calculated, such as the roughness average $\left(R_{a}\right)$, mean roughness depth $\left(R_{z}\right)$ and root mean square roughness $\left(R_{q}\right)$. The most commonly used parameters are $R_{a}$, which is defined as the arithmetic average of the absolute values of the measured heights from the mean surface taken within an evaluation area (15), and $R_{\mathrm{z}}$ the arithmetic mean value of the single roughness depths (the vertical distance between the highest peak and the deepest valley within a sampling length).

Contact profilometry technique is primarily designed for testing machined, ground or polished metal, and is usually performed in laboratories. Nevertheless, it is also employed on stone with varying amounts of success $(15,16)$. Grissom et al. (15) experienced difficulties in assessing surface roughness of macro-rough limestone and sandstone samples due to the gauge range of the stylus profilometer Surtronic 3+. Stylus profilometer is an instrument from which surface roughness is obtained by the locus of some points on the stylus, and the finite dimension of the stylus tip may not reach the bottom of deep stone pores and pits. The texture of stone is quite different from metal surfaces and thus the gauge range of the stylus cannot measure deep stone pores and pits, which are generally absent from such metal surfaces. Therefore, for rough stones and for in situ application the measurements are limited.

More recently, non-contact optical profilometers have been employed based on the principle of two-beam optical interferometry (14). Various non-contact techniques, such as laser-based systems and confocal profilometry are now widely used in industry. The later uses the principles of confocal microscopy; the device is positioned perpendicular to the object and scans the 
y escanea la superficie, capturando una serie de imágenes de alta resolución en profundidad del objeto. Cada imagen es entonces convertida a coordenadas $x-y-z$, creando mapas topográficos de los que pueden calcularse los parámetros de rugosidad. Estas técnicas sin contacto pueden clasificarse como no destructivas puesto que no tocan la superficie, evitando así daños al objeto.

En este estudio se determinan la rugosidad superficial de la piedra y la biomasa fotosintética, lo que permite correlacionar la influencia de la rugosidad superficial en la colonización epilítica de tres calizas diferentes. La aplicación de técnicas no destructivas para la medida de la rugosidad y la cuantificación de la biomasa es de gran interés en estudios de conservación del patrimonio.

\section{MATERIAL Y MÉTODOS}

\subsection{Litotipos}

La influencia de la rugosidad superficial en la colonización epilítica se evaluó en calizas de tres tipos:

- Caliza de Ançã (Portugal): caliza del jurásico de grano fino, compacta y tendencia oolítica, con $19 \%$ de porosidad abierta (17).

- Caliza de Lioz (Portugal): caliza del Cretácico Medio, microcristalina y de grano muy fino, con $0,5 \%$ de porosidad abierta (17), estilolitos y bioclastos recristalizados.

- Piedra de Lecce (Italia): caliza miocena de grano fino, casi exclusivamente compuesta de bioclastos recristalizados y de cementación escasa, que conlleva una alta porosidad abierta $(43,2 \%)(17)$.

Estos litotipos han sido ampliamente utilizados en monumentos románicos, góticos, renacentistas, barrocos y neoclásicos, y todavía se emplean en la construcción de edificios y escultura. Información detallada sobre sus propiedades petrofísicas y petrográficas ha sido publicada recientemente (17). Las muestras pétreas se obtuvieron de las canteras de Portunhos y Pero-Pinheiro (Portugal) y Lecce (Italia) respectivamente, posteriormente fueron cortadas en cilindros de $4,4 \mathrm{~cm}$ de diámetro y 3 $\mathrm{cm}$ de altura con una sierra circular de diamante. Sus superficies se terminaron usando caborundum 180 (carburo de silicio), sin ningún otro acabado superficial.

\subsection{Medidas de rugosidad}

La rugosidad superficial se midió en los tres litotipos utilizando un perfilómetro óptico para la medida de la rugosidad superficial, TRACEiT ${ }^{\circledR}$, patentado por Innowep $\mathrm{GmbH}$, surface, capturing a series of high depth resolution images of the object. Each image is then converted to $x-y-z$ coordinates, creating topographical maps and roughness parameters can be calculated. These non-contact techniques can be classified as non-destructive techniques since do not touch the surface, not damaging the object.

In this study, the usefulness of quantifying stone surface roughness is demonstrated by assessing photosynthetic biomass on stone samples, allowing the correlation of surface roughness influence on the epilithic colonisation of three different limestones. Non-destructive techniques for roughness measurements and biomass quantification is of great interest in the cultural heritage field for fulfilling the mission of heritage preservation.

\section{MATERIALS AND METHODS}

\subsection{Lithotypes}

The influence of surface roughness on the epilithic colonisation was assessed in three types of limestones:

- Ançã limestone (Portugal): fine-grained, compact to oolitic tendency limestone from the Jurassic, with $19 \%$ open porosity (17).

- Lioz limestone (Portugal): microcrystalline, very finegrained limestone from the middle Cretaceous, with $0.5 \%$ open porosity (17), and showing stylolite joints and recrystallised bioclasts.

- Lecce stone (Italy): fine-grained Miocene limestone, almost exclusively composed by sparite bioclasts and scarce cementation leading to high open porosity (43.2\%) (17).

All of these lithotypes were widely used in Romanesque, Gothic, Renaissance, Baroque and Neoclassical monuments, and are still being used in the construction of modern buildings and sculptures. Detailed information regarding their petrographic and petrophysical properties was presented in Miller et al. (17). Stone samples were obtained from quarries at Portunhos and Pero-Pinheiro (Portugal), and Lecce (Italy), respectively. Later the samples were cut into cylinders with $4.4 \mathrm{~cm}$ diameter and $3 \mathrm{~cm}$ height using a circular diamond swan. Their surfaces were finished using carborundum 180 (silicium carbide), without any other surface finish.

\subsection{Roughness measurements}

The surface roughness was measured on the three lithotypes using a non-contact optical surface roughness instrument, TRACEIT ${ }^{\circledR}$ patented by Innowep $\mathrm{GmbH}$, 
que se eligió en función de su alto rango de medida, facilidad de manejo e interés de los datos obtenidos. Se evaluaron parámetros de rugosidad como $R_{a}(\mu m)$ y $R_{z}$ $(\mu \mathrm{m})$ de cinco longitudes de muestreo consecutivas. Los parámetros de rugosidad analizados se calcularon y definieron como estipula la norma ISO 4287:1984 (18). En aras de la brevedad, solo los valores medios de $R_{a}$ y $R_{z}$ se citan en este trabajo. Un área estándar de $5 \times 5 \mathrm{~mm}$ fue escaneada para cada medida y se midieron cuatro áreas en las superficies superior e inferior de cada muestra. Se midieron tres muestras por litotipo y se promediaron los resultados. La resolución fue de 2,5 $\mu \mathrm{m}$ (eje Z) y $2,5 \mu \mathrm{m}$ (ejes $X / Y$ ), el número de puntos captado en los ejes $X / Y$ fue de 2.000 y la longitud del corte fue de $0,80 \mathrm{~mm}$. Los mapas microtopográficos en 3D se elaboraron con la máxima resolución (1.528 píxeles en las direcciones $\mathrm{x}$ e $\mathrm{y}$ ). El sistema de medida consiste en un sensor conectado a un ordenador portátil modificado. Los datos obtenidos se analizaron con el software TRA$\mathrm{CEiT}{ }^{\circledR}$, que presenta la impresión visual (apariencia de la superficie medida en tonos de gris) y la topografía 3D. La topografía 3D se documentó mediante los parámetros de rugosidad y sus desviaciones típicas.

\subsection{Cuantificación de biomasa fotosintética}

La utilidad de la cuantificación de la rugosidad superficial se ilustró mediante la evaluación de la biomasa fotosintética obtenida en un experimento de colonización llevado a cabo en laboratorio en el que los tres litotipos calcáreos se inocularon con un cultivo de microorganismos fototróficos y se incubaron en una cámara climática durante 90 días (17).

Para cuantificar y monitorizar el desarrollo de los microorganismos fotosintéticos sobre las muestras durante el tiempo de incubación se empleó análisis digital de imágenes. Estas técnicas de análisis digital de imágenes constituyen un conjunto de herramientas de bajo coste y gran utilidad que permiten el registro y cuantificación no destructiva de los diferentes elementos que aparecen en las imágenes digitales, incluso cuando estos no son reconocibles a simple vista. Las áreas de la superficie de las piedras cubiertas por los biofilms se determinaron comparando por triplicado las mismas muestras en diferentes periodos de incubación. Para poder llevar a cabo cualquier tipo de comparación, es esencial situar cada muestra en las mismas condiciones de registro, permitiendo que la toma de datos sea repetible. Así, después de periodos de incubación de 0,45 y 90 días, las muestras pétreas ( $n=3$ para cada tipo de caliza) se extrajeron de la cámara climática y se colocaron sobre papel milimetrado bajo condiciones de luz controladas para asegurar condiciones fijas para todos los registros fotográficos. Las which was chosen for its great gauge range, simple execution and interesting data obtained. Roughness parameters like $R_{a}(\mu m)$ and $R_{z}(\mu m)$ of five consecutive sampling lengths were evaluated. The roughness parameters analysed were calculated and defined as stipulated in standard ISO 4287:1984 (18). For brevity, only their $R_{a}$ and $R_{z}$ average values are reported in this paper. A standard area of $5 \times 5 \mathrm{~mm}$ was surveyed for each measurement and four sampling areas of each stone sample were measured on the top and bottom surfaces of the samples. Three stone samples of each lithotype were measured and the results were averaged. The resolution was $2.5 \mu \mathrm{m}$ ( $Z$ axe) and $2.5 \mu \mathrm{m}$ (in $X / Y$ axes), the number of data points in $X / Y$ axes was 2000 and the cut off used for calculations was $0.80 \mathrm{~mm}$. 3D micro-topography maps were also performed with the highest resolution (1528 pixels in $x$ and $y$ directions). The measuring system consists of a sensing head connected to a special, modified notebook, in which storage, evaluation and analysis occur. The measured data were analysed by the TRACEIT ${ }^{\circledR}$ software, which shows the visual impression (appearance of the measured surface in gray tones) and the computed $3 D$ topography maps. The $3 D$ topography was documented by the roughness parameters and their standard deviations.

\subsection{Quantification of photosynthetic biomass}

The usefulness of quantifying surface roughness was illustrated by assessing photosynthetic biomass data from a laboratory-based stone colonisation experiment, in which the three lithotypes were inoculated with a culture of phototrophic microorganisms and incubated in a climatic chamber during 90 days (17).

Digital image analysis was applied to quantify and monitor the development of photosynthetic growth on the stone samples during the incubation time. Digital image analysis techniques constitute a low-cost and very useful set of tools allowing non-destructive recording and quantification of different elements included in digital images even when they are not recognised by eye. The stone surface areas covered by the biofilms were determined by comparing in triplicate the same stone samples in different incubation periods. To perform either type of comparison, it is essential to place each sample in the same recording conditions, allowing the data collection process to be repeatable. Therefore, after incubation periods of 0, 45 and 90 days, stone samples ( $n=3$ per limestone type) were taken out of the climatic chamber and placed on millimetric paper under controlled light to ensure fixed conditions for all photographic records. The photographic recording was performed with a digital camera (Kodak EasyShare P850); the generated RGB digital images were 
tomas fotográficas se efectuaron con una cámara digital (Kodak EasyShare P950); las imágenes RGB generadas se transfirieron a un ordenador personal y se procesaron para rectificar digitalmente la geometría de las imágenes y hacerlas así geométricamente consistentes con propósitos comparativos. Para la rectificación digital de las imágenes fotográficas se utilizó el software Adobe Photoshop ${ }^{\circledR}$ siguiendo a Mark y Billo (19). El resultado de estas correcciones geométricas es un archivo multicapa, en el que cada capa corresponde a uno de los estadios de incubación registrados.

Puesto que el color y la textura de algunos litotipos podían enmascarar la presencia de los biofilms sobre sus superficies, las imágenes RGB previamente rectificadas geométricamente fueron descorrelacionadas mediante Análisis de Componentes Principales (PCA), utilizando el programa HyperCube v. 9.5 (Army Geospatial Centre, Alexandria, Virginia, EE UU) para la mejora de la visualización. En general, las Componentes Principales (PC) de una imagen pueden calcularse de acuerdo con [1]: transferred and processed on a personal computer in order to digitally rectify the geometry of the images making them geometrically consistent for comparative purposes. Adobe Photoshop ${ }^{\circledR}$ software was used for the digital rectification of single photographs as shown by Mark and Billo (19). The result of these geometric corrections is a multi-layer file, in which each layer corresponds to one of the incubation stage recorded.

Since the colour and texture of some lithotypes may mask the presence of the biofilms on their surfaces, geometrically rectified $R G B$ images were then decorrelated by Principal Component Analysis (PCA), using the HyperCube v. 9.5 software (Army Geospatial Centre, Alexandria, Virginia, USA) for image enhancement. In general, the Principal Components (PC) of an image can be calculated according to [1]:

$$
P C_{j}=\sum_{i=1, p} a_{i j} N_{i}+R_{j}
$$

donde $P C_{j}$ es el valor del píxel que corresponde a la Componente Principal $j, a_{i, j}$ es el coeficiente aplicado al valor del píxel de la banda $i$ para generar el Componente $j$ y $R_{j}$ una constante introducida en cada Componente para evitar valores negativos.

Este enfoque permite la detección de los elementos minoritarios (de diferente naturaleza y composición) aparentemente ausentes en la imagen inicial RGB por estar enmascarados por los datos redundantes registrados en las bandas roja, verde y azul de la imagen. Mediante esta descorrelación es posible elegir la banda correspondiente a cada $\mathrm{PC}\left(\mathrm{PC}_{1}, \mathrm{PC}_{2} \circ \mathrm{PC}_{3}\right)$ más apropiada para mejorar la visualización de la biomasa fotosintética presente sobre la superficie de las piedras. Con posterioridad se aplicó un algoritmo de segmentación iterativo de manera que las imágenes pudieran transformarse en binarias, seleccionándose las áreas a cuantificar. La binarización de la imagen se basa en el reconocimiento de los valores extremos de píxel de las coberturas identificadas visualmente como biomasa. Típicamente, los algoritmos iterativos de segmentación trabajan utilizando el promedio de la media de las clases primer plano y fondo, estableciendo un nuevo umbral $\left(T_{n}\right)$ mediante iteración (20). El algoritmo empleado en este trabajo fija el umbral de acuerdo a [2]:

$$
T_{n}=\left(g_{\max }-g_{\min }\right) \sum_{g=g_{\min }}^{g_{\text {mid }}^{*}} p(g)
$$

donde $g_{\max }$ es el mayor nivel de gris distinto de cero, $g_{\text {min }}$ es el más bajo, $g_{\text {mid }}$ es el punto medio entre los dos where $P C_{j}$ is the pixel value corresponding to Principal Component $j, a_{i, j}$ is the coefficient applied to the pixel vaule of $i$ band to generate the Component $j$ and $R_{j} a$ constant introduced in each Component to avoid negative values.

This approach allows the detection of minority elements (of different nature and composition) apparently absent in the initial RGB digital image but masked by the redundant data registered in the Red, Green and Blue bands of the image. With this decorrelation it is possible to choose the most appropriate band corresponding to each $P C\left(P C_{1}, P C_{2}\right.$ or $\left.P C_{3}\right)$ which enhance the visualisation of the photosynthetic biomass present on the stone surfaces. An iterative thresholding algorithm was then applied in order to segment the images into binary, selecting the colonised areas to be quantified. The binarisation of the image is based in the recognition of the extreme pixel values of the coverage visually identified as biomass. Typically, iterative thresholding algorithms work using the average of the foreground and background class means, establishing a new threshold $\left(T_{n}\right)$ by iteration (20). The algorithm employed in this work displays the threshold according to [2]:

where $g_{\max }$ is the highest nonzero grey level, $g_{\min }$ is the lowest one, $g_{\text {mid }}$ is the midpoint between the two 
puntos asumidos del histograma $\left[g_{\text {mid }}=\left(g_{\max }+g_{\min }\right) / 2\right]$, y $p(\mathrm{~g})$ es la función de probabilidad de masa.

Posteriormente las imágenes se escalaron y los píxeles seleccionados se contaron para una estimación del área. Todas estas operaciones de análisis de imágenes se llevaron a cabo con el programa Image] (National Institutes of Health, Bethesda, Maryland, EE UU). Como resultado, se obtuvo una serie de valores numéricos que permitieron la estimación de tasas de crecimiento a lo largo del periodo cubierto por el experimento.

\section{RESULTADOS Y DISCUSIÓN}

\subsection{Rugosidad superficial de la piedra}

La rugosidad superficial de los tres tipos de caliza se caracterizó mediante perfilometría óptica sin contacto. Las medidas revelaron que los litotipos estudiados incluían tanto piedras con valores de rugosidad superficial muy bajos (calizas de Ançã y Lioz) como con valores de rugosidad considerables (piedra de Lecce). Los parámetros de rugosidad calculados mediante el perfilómetro óptico TRACEiT ${ }^{\circledR}$ se presentan en la Tabla 1 . La diferencia en valores de rugosidad se relaciona con diferencias en el tamaño, forma y disposición de los componentes minerales de cada tipo de caliza. Los altos valores de rugosidad media aritmética $\left(R_{a}\right)$ y amplitud media de rugosidad $\left(R_{z}\right)$ obtenidos para la piedra de Lecce pueden estar relacionados con su alta porosidad abierta $(43,2 \%)$ aparentemente producida por la escasa cementación de la matriz micrítica que sobre todo incorpora bioclastos espariticos (microfósiles, fragmentos de fósiles y conchas).

La medida de la rugosidad superficial puede estar limitada por la resolución del instrumento de medida empleado, por lo que la textura superficial real puede estar falseándose debido a la dimensión de la punta de la aguja, de la velocidad de lectura del instrumento de aguja, del detector de fotodiodo o de la ampliación que permita el objetivo utilizado por los perfilómetros ópticos sin contacto (14). En este trabajo, las impresiones visuales y las representaciones 3D de las superficies pétreas obtenidas mediante perfilómetro óptico permitieron visualizar sus irregularidades, como se muestra en las Figuras 1-3. Parece claro que la caliza más rugosa es la piedra de Lecce (Figura 3), que muestra irregularidades assumed points of the histogram $\left[g_{\text {mid }}=\left(g_{\max }+g_{\min }\right) / 2\right]$, and $p(g)$ the probability mass function.

The images were afterwards scaled, and the selected pixels counted for area estimation. All these image operations were performed with ImageJ software (National Institutes of Health, Bethesda, Maryland, USA). A series of numerical values were obtained, allowing the estimation of growth rates along the experiment period.

\section{RESULTS AND DISCUSSION}

\subsection{Stone surface roughness}

The stone surface roughness of the three limestone types were characterised by non-contact optical profilometry. The measurements revealed that the studied lithotypes included either stones with very low surface roughness, namely Lioz and Ançã limestones, or with considerable roughness values, i.e. Lecce stone. The roughness parameters resulting from the calculations obtained by the optical profilometer TRACEIT ${ }^{\circledR}$ are presented in Table 1. The difference in roughness values are related to differences in the size, shape and arrangement of the mineral components of these of limestone. The great roughness average $\left(R_{a}\right)$ and the mean roughness depth $\left(R_{z}\right)$ values obtained for Lecce stone may be related with its high open porosity (43.2\%) apparently produced by scarce cementation of the very-fine micrite matrix which mainly incorporates sparite bioclasts (microfossils, fossil fragments and shells).

Surface roughness measurement can be limited by the resolution of surface measuring instruments where the real surface texture may be misrepresented owing to finite dimension of the stylus tip, reading speed of stylus instruments, photodiode detector and objective lens magnification used by a non-contact optical profilometer (14). In this study, the visual impression and 3D representation of the stone surfaces obtained under the non-contact optical profilometer allowed the visualisation of its irregularities, as shown in Figures 1-3. It is clear that the roughest limestone is Lecce stone (Figure 3), depicting widely homogeneous spaced irregularities. Lioz

Tabla 1. Valores medios \pm desviación típica de los parámetros de rugosidad superficial obtenidos con el perfilómetro óptico (TRACEiT®). Table 1. Mean values \pm standard deviation of surface roughness parameters obtained by optical profilometer (TRACEiT®).

\begin{tabular}{|c|c|c|}
\hline \multirow{2}{*}{ Litotipo / Lithotype } & Perfilómetro óptico / Optical profilometer & $(\boldsymbol{n}=\mathbf{2 4})$ \\
\cline { 2 - 3 } & $\mathbf{R}_{\mathbf{a}}(\boldsymbol{\mu m})$ & $\mathbf{R}_{\mathbf{z}}(\boldsymbol{\mu m})$ \\
\hline Caliza de Ançã / Ançã limestone & $1.59 \pm 0.38$ & $8.39 \pm 1.79$ \\
\hline Caliza de Lioz / Lioz limestone & $1.47 \pm 0.35$ & $7.51 \pm 1.62$ \\
\hline Piedra de Lecce / Lecce stone & $6.06 \pm 0.80$ & $27.53 \pm 3.10$ \\
\hline
\end{tabular}


espaciadas de modo bastante homogéneo. La caliza de Lioz, seguida por la caliza de Ançã, mostraban, por el contrario, una heterogeneidad superficial de pequeña escala, por lo que pueden definirse como calizas lisas (Figuras 1-2). La superficie lisa de la caliza de Lioz se debe probablemente a su fuerte recristalización, que conduce a un prominente desarrollo de cristales de carbonato esparítico donde existe contacto continuo de los cristales de calcita esparítica con sus vecinos. Por otra parte, los valores de rugosidad obtenidos para la caliza de Ançã pueden explicarse por su matriz de naturaleza micrítica en la que están presentes abundantes bioclastos con muy poco cemento micrítico espatizado. Debe mencionarse que todas las muestras se prepararon aplicando el mismo procedimiento y condiciones experimentales mediante una sierra de diamante, por lo que la rugosidad medida es el resultado de la acción combinada de factores pétreos que tuvieron lugar durante el proceso de pulido. Aunque la piedra de Lecce muestra una textura homogénea y de grano fino, es la alta porosidad abierta de este litotipo $(43,2 \%)$ la que puede producir su elevada rugosidad. limestone followed by Ançã limestone showed smallscale heterogeneity of the surface, and thus can be defined as smooth limestones (Figures 1-2). The smoothest stone surface of Lioz limestone is probably due to its strong recrystallisation, leading to a prominent sparite carbonate crystal development where a continuous contact of spary calcite crystals with their neighbours occurs. On the other hand the roughness values obtained for Ançã limestone may be explained by its matrix of micritic nature in which abundant bioclasts are present and contains very little spathised micritic cement. It must be mentioned that all stone samples were prepared applying the same procedure and experimental conditions using a diamond swan, and thus the measured roughness is the result of combined action of stone factors that occurred during the swan process. Although Lecce stone shows homogeneous and finegrained texture, it is the high open porosity of this lithotype (43.2\%) which may produce its elevated roughness.

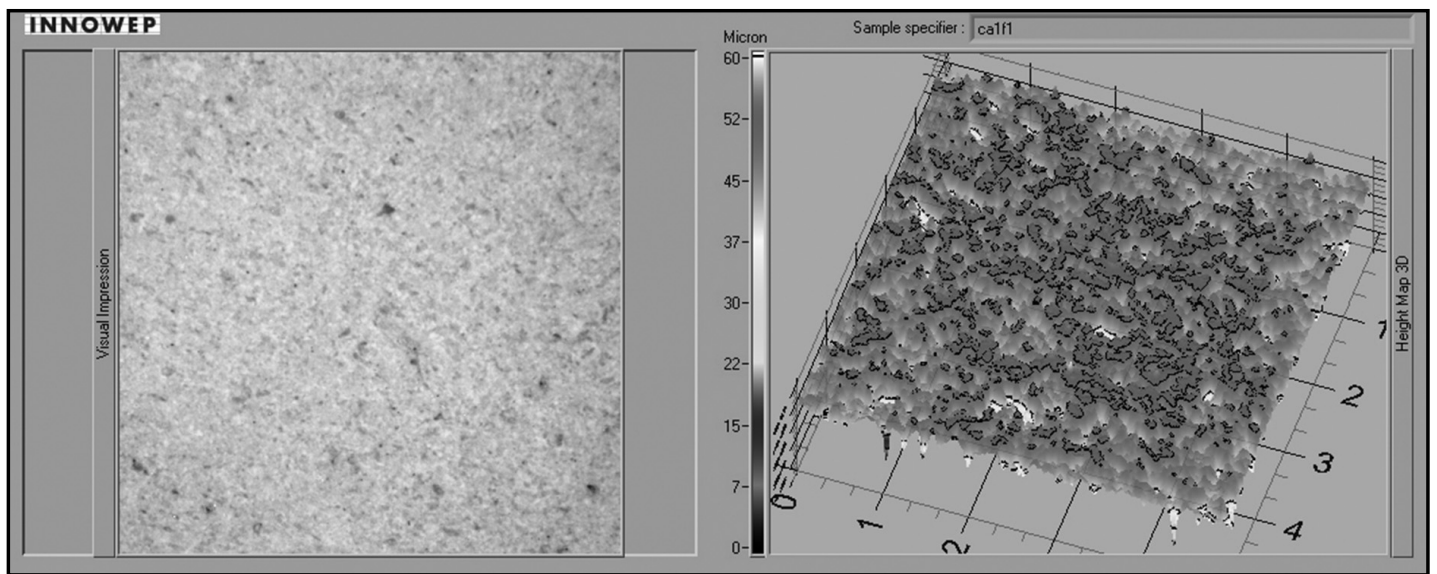

Figura 1. Impresión visual (izquierda) y topografía 3D de superficie (derecha) de un área medida representativa de caliza de Ançã. Figure 1. Visual impression (left image) and computed 3D surface topography (right image) of one representative measured area of Ançã limestone.

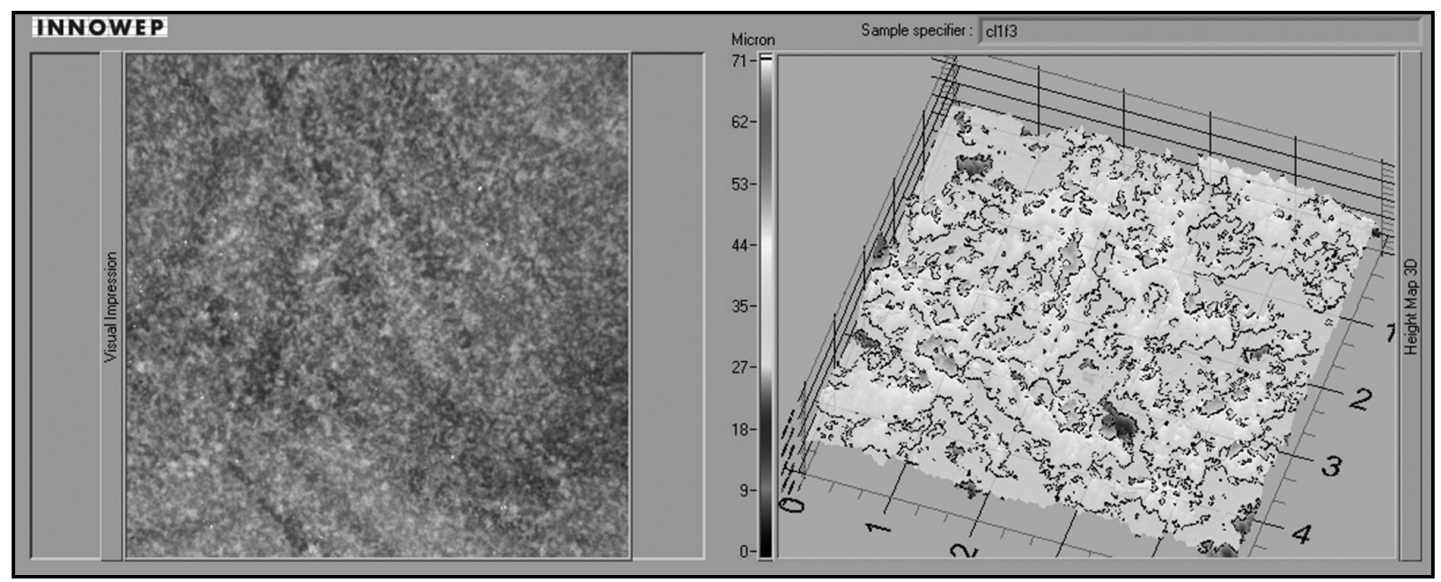

Figura 2. Impresión visual (izquierda) y topografía 3D de superficie (derecha) de un área medida representativa de caliza de Lioz. Figure 2. Visual impression (left image) and computed 3D surface topography (right image) of one representative measured area of Lioz limestone. 


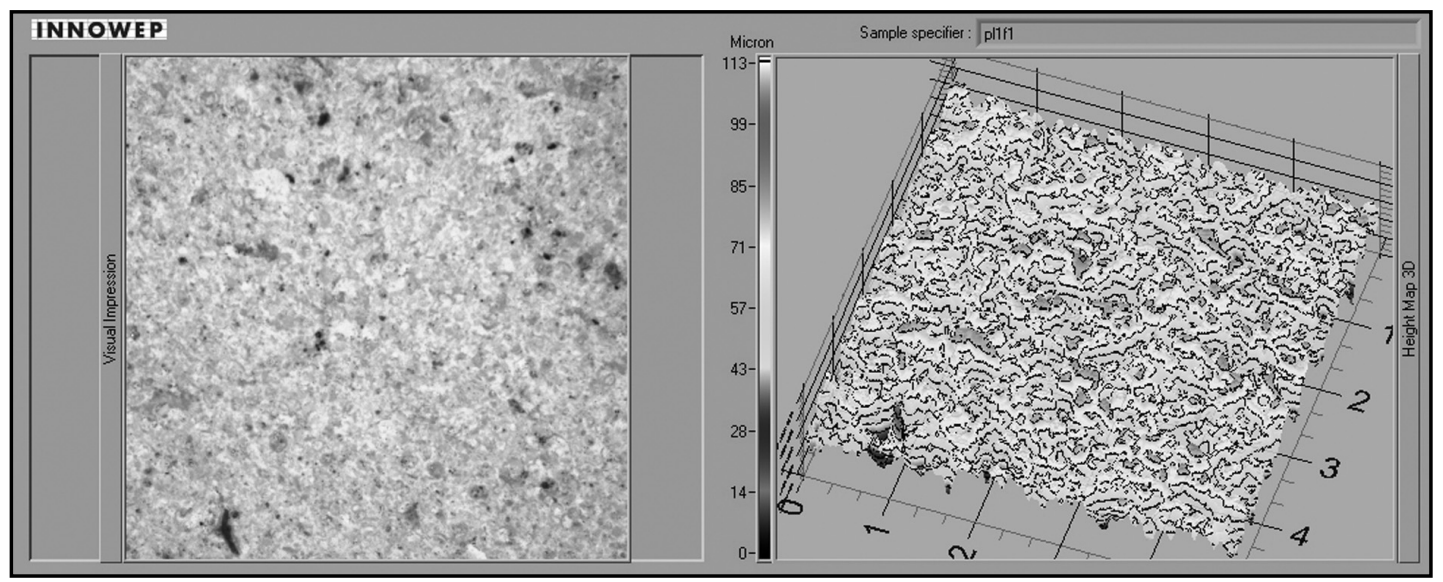

Figura 3. Impresión visual (izquierda) y topografía 3D de superficie (derecha) de un área medida representativa de piedra de Lecce. Figure 3. Visual impression (left image) and computed 3D surface topography (right image) of one representative measured area of Lecce stone.

El estudio de la rugosidad superficial permite evaluar la relación real entre la rugosidad superficial $\left(R_{a} \circ R_{z}\right)$ y una propiedad petrofísica de la piedra muy relacionada con las características petrográficas de estos materiales, como es la porosidad abierta (Figura 4). La correlación logarítmica positiva entre estas dos variables indica que pequeños cambios en la porosidad abierta de piedras poco porosas inducirán cambios pequeños en la rugosidad superficial de las mismas, mientras que para piedras más porosas pequeños cambios en este parámetro tienen mayor impacto en su rugosidad.

En resumen, la caliza de grano fino (piedra de Lecce) muestra la superficie más rugosa, mientras que la caliza de Lioz muestra la superficie más lisa. De los parámetros de rugosidad evaluados durante el experimento, puede establecerse un índice de rugosidad, siguiendo el orden ascendente de rugosidad: caliza de Lioz < caliza de Ançã $<$ piedra de Lecce. De acuerdo con este índice, puede predecirse que la rugosidad superficial de la piedra de Lecce puede proporcionar múltiples puntos de anclaje
Consideration of surface roughness enables testing the actual relationship between surface roughness (either $R_{a}$ or $R_{z}$ ) and a petrophysical property of the stone strongly related to petrographical characteristics of these materials, i.e., the open porosity (Figure 4). The positive logarithmic relationship between these two variables indicates that small changes in the open porosity of low porous stones will induce small changes in stone surface roughness, whereas for more porous stones small changes in this parameter have greater impact in their roughness.

In summary, the fine-grained limestone (Lecce stone) shows the roughest surface, whereas Lioz limestone shows the smoothest stone surface. Within the surface roughness parameters assessed during the experimental set-up, a roughness index can be established, following the increasing order of roughness: Lioz limestone < Ançã limestone < Lecce stone. According to this index it can be predicted that the surface roughness of Lecce stone may provide multiple attachment points to the settling of

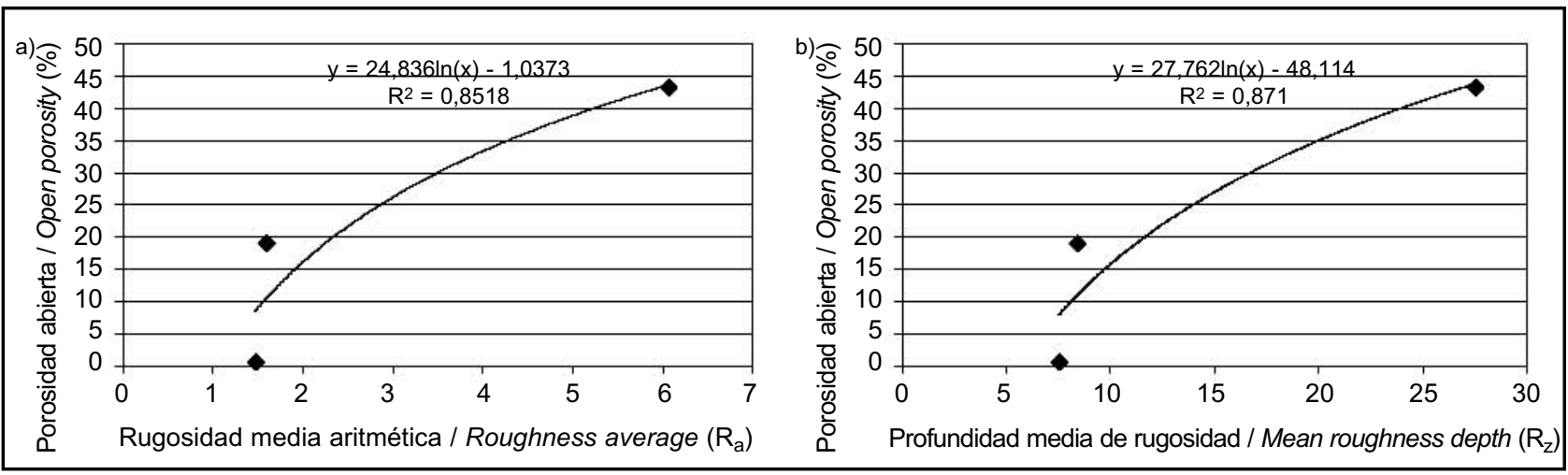

Figura 4. Relación entre la porosidad abierta y la rugosidad media aritmética $R_{a}$ (a) y la profundidad media de rugosidad $R_{z}$ (b). Datos de porosidad abierta de Miller et al. (17).

Figure 4. Relationship between the open porosity and roughness average $R_{a}$ (a) and mean roughness depth $R_{z}(b)$. Open porosity data are from Miller et al. (17). 
para el establecimiento de microorganismos y puede favorecer la retención de agua aumentándose la humedad superficial y como consecuencia el crecimiento y desarrollo microbianos.

\subsection{Biomasa fotosintética}

Para la cuantificación de la biomasa fotosintética a lo largo del tiempo de incubación, se midieron las áreas cubiertas por los biofilms utilizando análisis digital de imágenes (Figura 5). Mediante los algoritmos de segmentación aplicados a las bandas obtenidas por PCA fue posible aislar las áreas cubiertas por el biofilm y cuantificar la cubierta fototrófica a lo largo del tiempo, como representa la Figura 6. El cultivo líquido de microorganismos fototróficos inoculado sobre las superficies líticas (día 0) creció durante el tiempo de incubación produciendo un incremento del área superficial cubierta en las muestras de piedra de Lecce. Después de 45 y 90 días de incubación se observó un incremento abrupto y sostenido de la biomasa, revelando un crecimiento epilítico significativo (Figura 6). Para el litotipo menos rugoso (caliza de Lioz), se observó durante el tiempo de incubación un incremento muy ligero del área cubierta, esperable debido a su naturaleza compacta y a sus características petrofísicas. Las áreas cubiertas por biofilm en las muestras de caliza de Ançã se redujeron durante los primeros 45 días de incubación, permaneciendo estabilizadas tras este periodo (Figura 6). Sin embargo, tras 90 días de incubación, se detectó un ligero incremento de la biomasa fotosintética lo que sugiere que la colonización fototrófica se incrementaría progresivamente si se extendiera el período de incubación. De acuerdo con Roeselers et al. (21), el fin del crecimiento exponencial no significa necesariamente que una comunidad estable se haya asentado, o que por el contrario la colonización haya cesado. El biofilm puede estar todavía en un estado de adaptación, desarrollándose lentamente hacia una convergencia final. microorganisms and may encourage entrapment of water increasing surface wetness and consequently microbial growth and development.

\subsection{Photosynthetic biomass}

For the quantification of photosynthetic biomass along the incubation time span, the measurement of areas covered by the biofilms was performed by digital image analysis (Figure 5). By means of the thresholding algorithms applied to bands obtained by PCA, it was possible to isolate the areas covered by the biofilm and quantify the phototrophic cover through the time as represented in Figure 6. The phototrophic liquid culture inoculated on the lithic surfaces (day 0), have grown during the incubation course leading to an increase of surface covered areas on Lecce stone samples. After 45 and 90 days of incubation an abrupt and steady increase of biomass was observed, revealing significant epilithic growth (Figure 6). For the less rough lithotype (Lioz limestone), a very slight increase of stone surface covered area was observed during the incubation, which was expected due to its very compact nature and petrophysical characteristics. The stone surface covered areas of Ançã limestone decreased during the first 45 days of incubation, remaining constant after this incubation period (Figure 6). However, a very slight increase of photosynthetic biomass was noticed after 90 days of incubation, suggesting that the phototrophic colonisation would progressively increase if the incubation period were extended. According to Roeselers et al. (21), the end of exponential growth does not necessarily mean that a stable climax community has established or cessed. The biofilm may be still in an adaptation state, developing slowly towards a final convergence.

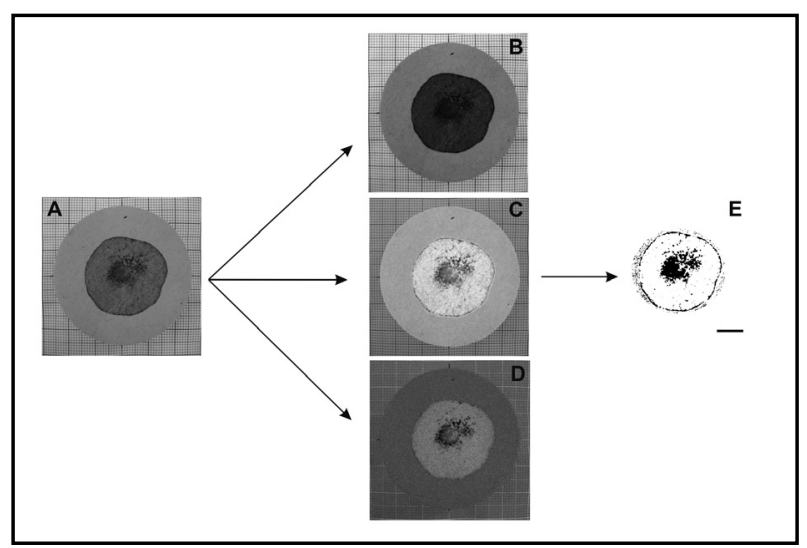

Figura 5. Protocolo de análisis digital de imágenes empleado para la cuantificación de biomasa. (a) Imagen RGB original a los 90 días de incubación de la caliza de Ançã; (b) banda correspondiente a la $\mathrm{PC}_{1} ;$ (c) banda correspondiente a la $\mathrm{PC}_{2} ;$ (d) banda correspondiente a la $\mathrm{PC}_{3}$, obtenidas mediante descorrelación de imágenes, y (e) imagen binaria.

Figure 5. Digital image analysis protocol used for biomass quantification. (a) original RGB image at 90 days-incubation of Ançã limestone. (b) $P C_{1}$ band; (c) $P C_{2}$ band; (d) $P C_{3}$ band, obtained by image decorrelation, and (e) binary image. 


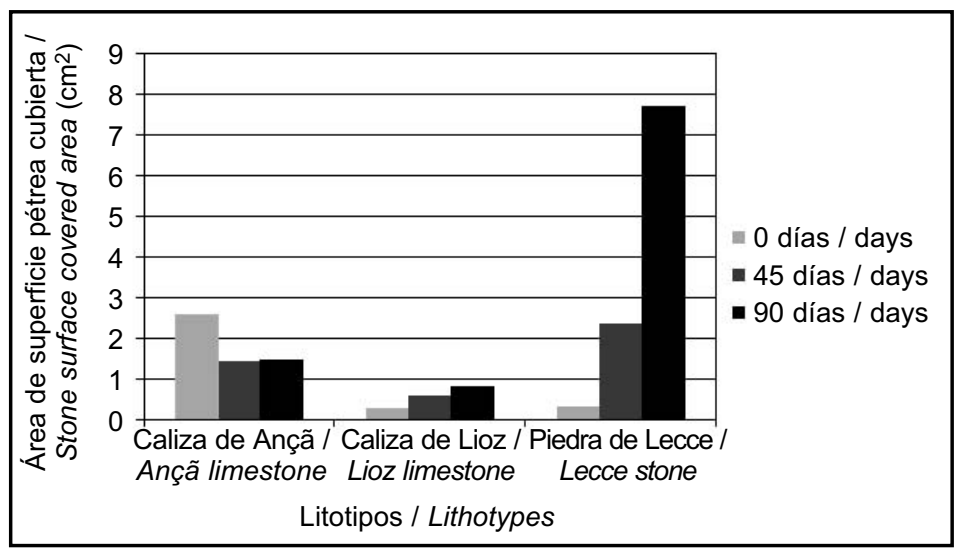

Figura 6. Suma de las áreas superficiales de las piedras cubiertas por los biofilms, cuantificadas mediante análisis digital de imágenes. Figure 6. Sum of the stone surface areas covered by the biofilms, quantified by digital image analysis.

El área de las superficies pétreas cubierta por colonización fotosintética se consideró una medida del crecimiento fotosintético. Cuantificando la superficie cubierta por los biofilms era posible evaluar qué muestras eran las que mostraban una superficie más extensamente colonizada. Consecuentemente, la piedra de Lecce reveló el crecimiento epilítico más significativo, resultando intensamente colonizada por microorganismos fototróficos a los 90 días de incubación. La caliza de Ançã sólo fue colonizada superficialmente y la caliza de Lioz mostró las áreas superficiales colonizadas más reducidas, casi carentes de crecimiento fotosintético. Estos resultados concuerdan con los obtenidos meidante fluorescencia in vivo de la clorofila a usada para analizar cinco tipos de caliza, entre los que se incluían las muestras pétreas presentadas en este trabajo (17). Ambas técnicas no destructivas permitieron la cuantificación y la monitorización de biofilms fototróficos epilíticos, incluso en un estado incipiente en el que era difícil apreciar el color verde característico de la clorofila.

Así, el análisis digital de imágenes se ha revelado como una importante herramienta para la detección de la colonización epilítica fotosintética sobre la piedra de monumentos, puesto que su bajo coste y la portabilidad del método permite obtener medidas rápidas y observaciones cuantificadas en menos tiempo que las técnicas convencionales, así como obtener medidas sucesivas sin necesidad de destruir las muestras, algo de gran interés para estudios de monitorización in situ, especialmente sobre bienes del patrimonio cultural. Además, estas técnicas cuantitativas de monitorización visual han demostrado gran sensibilidad para la detección de muy bajas concentraciones de biomasa fotosintética, permitiendo la detección de organismos fotótrofos en un temprano estadio de crecimiento sobre las superficies pétreas.

En lo que concierne a la influencia de la rugosidad superficial de la piedra en el desarrollo de colonización fotosintética, este estudio demuestra su dependencia de la
The stone surface areas covered by photosynthetic biofilms were considered a measure of photosynthetic growth. By quantifying the surface areas covered by biofilms, it was possible to assess which samples showed the most extensively colonised surface. Consequently, Lecce stone revealed the most significant epilithic growth, being strongly colonised by phototrophic microorganisms at 90 days of incubation. Ançã limestone was merely colonised on its surfaces and Lioz limestone showed the lowest surface colonisation areas, being almost devoid of photosynthetic growth. These results are in accordance with those obtained by in vivo chlorophyll a fluorescence used to analyse five limestone types, including the stone samples tested in this work (17). Both non-destructive techniques allowed the quantification and monitoring of epilithic phototrophic biofilms, even in an incipient stage when it was difficult to visually appreciate the green colour characteristic of chlorophyll.

Hence, digital image analysis revealed to be an important tool for the detection of epilithic photosynthetic colonisation on monument stones, since it is a low-cost and easy to handle method, produces rapid measurements and quantified observation in less time than conventional methods, and allow successive measurements without destroying the samples, which has a great interest for in situ monitoring studies especially on cultural heritage assets. Moreover, these visual monitoring quantitative techniques showed high sensitivity for the detection of very low concentrations of photosynthetic biomass allowing the detection of phototrophs at an early growth stage on the stone surfaces.

In what concerns the influence of stone surface roughness in the development of photosynthetic colonisation, this study demonstrated its dependence on 
rugosidad superficial. La extensión de la colonización microbiana se incrementaba cuando lo hacía la rugosidad superficial (Figura 7). Esto se debe a que las fuerzas transversales disminuyen y el área superficial total es mayor en las superficies rugosas $(22,23)$. Del mismo modo, la caliza más lisa (caliza de Lioz) mostró la tendencia más baja a ser colonizada por microorganismos fototróficos, lo que puede hacerla apropiada para el uso exterior en edificios y estatuaria. Por el contrario, las piedras con altos valores de rugosidad superficial, como la piedra de Lecce, serán más susceptibles al deterioro físico, químico y biológico. Las irregularidades de la superficie proporcionaron puntos de anclaje y micronichos para el asentamiento de células microbianas sobre las muestras de piedra de Lecce, favoreciendo su crecimiento. Estos resultados concuerdan con los obtenidos por Guillitte y Dreesen (4), Tiano et al. (12), Tomaselli et al. (6) y Bergey (13).

El estudio de la rugosidad superficial de las piedras ha permitido comprobar la relación entre rugosidad y colonización por microorganismos fotosintéticos, obteniéndose una relación no lineal entre estos dos parámetros $\left(R^{2}=0,99\right)$. Los substratos más lisos, como las calizas de Lioz y Ançã presentan áreas superficiales menos cubiertas por biofilms. La relación logarítmica indica que pequeños cambios en la rugosidad superficial de substratos lisos tiene mayor impacto en la biomasa fotosintética que pequeños cambios en la rugosidad de substratos rugosos. Bergey (13) obtuvo resultados similares.

\section{CONCLUSIONES}

En este trabajo se analizó la topografía 3D de las superficies para estudiar la importancia de la rugosidad superficial de substratos líticos en el desarrollo de la colonización microbiana epilítica. De acuerdo con la rugosidad media aritmética $\left(R_{a}\right)$ y la amplitud media de rugosidad the surface roughness. The extent of microbial colonisation appeared to increase as the surface roughness increased (Figure 7). This is because shear forces are diminished, and total surface area is higher on rougher surfaces $(22,23)$. Indeed, the smoothest limestone (Lioz limestone) showed the lowest tendency to be colonised by phototrophic microorganisms. This can render it suitable for use in outdoor buildings and statuary. On the other hand, stones with high values of surface roughness, such as Lecce stone, will be more susceptible to physical, chemical and biological deterioration. The irregularities of the stone surfaces provided attachment points and microniches for the settlement of microbial cells on Lecce stone samples, favouring their growth. These results are in accordance with those reported by Guillitte and Dreesen (4), Tiano et al. (12), Tomaselli et al. (6) and Bergey (13).

Consideration of stone surface roughness enables testing the actual relationship between roughness and photosynthetic colonisation. A non-linear relationship between these two parameters (with an adjusted $R^{2}=0.99$ ) were obtained. Smoother substrates, such as Lioz and Ançã limestones, present lower surface covered area. The logarithmic relationship indicates that small changes in the surface roughness of smoother substrates will have greater impact on photosynthetic biomass than small changes in the roughness of rough substrates. Similar results were obtained by Bergey (13).

\section{CONCLUSIONS}

In this work, the surface 3D topography was analysed to study the importance of surface roughness of lithic substrates in the development of epilithic microbial colonisation. According to the roughness average $\left(R_{a}\right)$ and mean roughness depth $\left(R_{\mathrm{Z}}\right)$ determined for Ançã

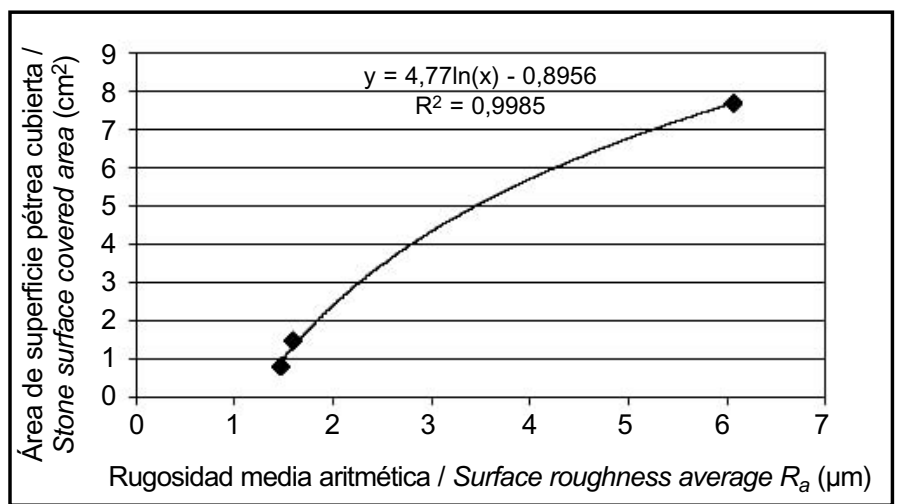

Figura 7. Relación entre la rugosidad media aritmética $\left(R_{a}\right)$ y el área de la superficie pétrea cubierta, medida mediante análisis digital de imágenes tras 90 días de incubación.

Figure 7. Relationship between the surface roughness average $\left(R_{a}\right)$ and stone surface covered area measured by digital image analysis after 90 days of incubation. 
$\left(R_{z}\right)$ determinadas para la caliza de Ançã, la caliza de Lioz y la piedra de Lecce, puede concluirse que las piedras con gran rugosidad superficial son propensas a la colonización microbiana. Así, se recomienda precaución para el uso del litotipo Lecce como piedra ornamental en exteriores sin tratamiento preventivo.

Con respecto a las técnicas aplicadas en este trabajo, el atractivo del perfilómetro óptico sin contacto TRACEiT ${ }^{\circledR}$ reside en la visión topográfica $3 \mathrm{D}$ de la distribución de las irregularidades sobre la superficie, que se suma a su amplio rango de medida. Esto lo hace interesante para estudios de monitorización in situ, al igual que el análisis digital de imágenes. Estas técnicas son rápidas, fiables y no destructivas, lo que tiene más relevancia cuando las muestras pertenecen a bienes del patrimonio cultural.

Además, el análisis digital de imagen permitió una evaluación cuantitativa bastante buena de las variaciones de la biomasa fotosintética en las muestras de caliza a lo largo del experimento de colonización en laboratorio. Este método permite obtener medidas rápidas de la biomasa fotosintética sobre substratos sólidos sin muestreo, pudiendo usarse para detectar microorganismos fototróficos sobre monumentos, así como para monitorizar fenómenos de biodeterioro.

\section{AGRADECIMIENTOS}

Este estudio ha sido financiado por el Ministério da Ciência, Tecnologia e Ensino Superior, Portugal, con una beca postdoctoral (SFRH/BPD/63836/2009) y parcialmente financiado por CEPGIST-FCT subproyecto DECASTONE. Este trabajo recibió también financiación del Programa de Financiamento Plurianual de Unidades de Investigação da FCT, financiado por la Unión Europea, FEDER, y fondos nacionales de la República Portuguesa. Este es un trabajo del proyecto CONSOLIDER CSD200700058. limestone, Lioz limestone and Lecce stone, it can be concluded that great surface roughness stones render them prone to microbial colonisation. Thus, precaution is recommended when using Lecce lithotype as ornamental stone in outdoor environments without preventive treatments.

Concerning the techniques applied in this work, the attractiveness of the non-contact optical profilometer $T_{R A C E I T}{ }^{\circledR}$ is the $3 D$ topographic view of the irregularities distribution on the surface, in addition to its high gauge range of measuring. It is of great interest for in situ monitoring studies as well as digital image analysis. These are rapid, reliable and non-destructive techniques, which take more relevance when samples belong to cultural heritage assets.

In addition, digital image analysis gave a rather good quantitative evaluation of photosynthetic biomass variations on the limestone samples along the laboratorybased colonisation experiment. This method allows rapid measurements of photosynthetic biomass on solid substrates without sampling procedures and can be used to detect phototrophic microorganisms on monuments, as well as to monitor biodeterioration phenomena.

\section{ACKNOWLEDGEMENTS}

This study has been financed by the Ministério da Ciência, Tecnologia e Ensino Superior, Portugal, with a postdoctoral grant (SFRH/BPD/63836/2009) and partially financed by CEPGIST-FCT subproject DECASTONE. This work also received support from Programa de Financiamento Plurianual de Unidades de Investigação da FCT, financed by European Union, FEDER, and national budget of the Portuguese Republic. This is also a paper from the project CONSOLIDER CSD2007-00058.

\section{BIBLIOGRAFÍA / BIBLIOGRAPHY}

(1) Guillitte, O.: "Bioreceptivity: "A new concept for building ecology studies", Sci. Total Environ., vol. 167 (1995), pp. $215-220$. http://dx.doi.org/10.1016/0048-9697(95)04582-L

(2) Bellinzoni, A. M.; Caneva, G.; Ricci, S.: "Ecological trends in travertine colonisation by pioneer algae and plant communities", Int. Biodet. Biodegr., vol. 51 (2003), pp. 203-210. http://dx.doi.org/10.1016/S0964-8305(02)00172-5

(3) Gorbushina, A. A.: "Life on the rocks", Environ. Microbiol., vol. 9 (2007), pp. 1613-1631. http://dx.doi.org/10.1111/j.14622920.2007.01301.x

(4) Guillitte, O.; Dreesen, R.: "Laboratory chamber studies and petrographical analysis as bioreceptivity assessment tools of building materials", Sci. Total Environ., vol. 167 (1995), 365-374. http://dx.doi.org/10.1016/0048-9697(95)04596-S

(5) Silva, B.; Prieto, B.; Rivas, T.; Sánchez-Biezma, M. J.; Paz, G.; Carhallal, R.: "Rapid biological colonization of a granitic building by lichens", Int. Biodet. Biodegr., vol. 40 (1997), pp. 263-267. http://dx.doi.org/10.1016/S0964-8305(97)00051-6

(6) Tomaselli, L.; Lamenti, G.; Bosco, M.; Tiano, P.: "Biodiversity of photosynthetic micro-organisms dwelling on stone monuments", Int. Biodet. Biodegr., vol. 46 (2000), pp. 251-258. http://dx.doi.org/10.1016/S0964-8305(00)00078-0 
(7) Prieto, B.; Silva, B.: "Estimation of the potential bioreceptivity of granitic rocks from their intrinsic properties", Int. Biodet. Biodegr., vol. 56 (2005), pp. 206-215. http://dx.doi.org/10.1016/j.ibiod.2005.08.001

(8) Scardino, A. J.; Guenther, J.; De Nys, R.: "Attachment point theory revisited: the fouling response to a microtextured matrix", Biofouling, vol. 24 (2008), pp. 45-53. http://dx.doi.org/10.1080/08927010701784391

(9) Scardino, A. J.; Harvey, E.; De Nys, R.: "Testing attachment point theory: diatom attachment on microtextured polyimide biomimics", Biofouling, vol. 22 (2006), pp. 55-60. http://dx.doi.org/10.1080/08927010500506094

(10) Alonso, F. J.; Vázquez, P.; Esbert, R.; Ordaz, J.: "Ornamental granite durability: evaluation of damage caused by salt crystallization", Mater. Construcc., vol. 58 (2008), pp. 191-201.

(11) Hodson, M. E.; Lee, M. R.; Parsons, I.: "Origins of the surface roughness of unweathered alkali feldspar grains", Geochim. Cosmochim. Acta, vol. 61 (1997), pp. 3885-3896. http://dx.doi.org/10.1016/S0016-7037(97)00197-X

(12) Tiano, P.; Accolla, P.; Tomaselli, L.: "Phototrophic biodeteriogens on lithoid surfaces: An ecological study", Microb. Ecol., vol. 29, (1995), pp. 299-309. http://dx.doi.org/10.1007/BF00164892

(13) Bergey, E. A.: "Measuring the surface roughness of stream stones", Hydrobiologia, vol. 563 (2006), pp. $247-252$. http://dx.doi.org/10.1007/s10750-006-0016-4

(14) Poon, C. H.; Bhushan, B.: "Comparison of surface roughness measurements by stylus profiler, AFM and non-contact optical profiler", Wear, vol. 190 (1995), pp. 76-88. http://dx.doi.org/10.1016/0043-1648(95)06697-7

(15) Grissom, C. A.; Charola, A. E.; Wachowiak, M. J.: "Measuring surface roughness on stone: back to basics", Stud. Conserv.; vol. 45 (2000), pp. 73-84. http://dx.doi.org/10.2307/1506665

(16) Benavente, D.; Martínez-Verdú, F.; Bernabeu, A.; Viqueira, V.; Fort, R.; García del Cura, M. A.; Illueca, C.; Ordóñez, S.: "Influence of surface roughness on color changes in building stones", Color Res. Appl., vol 28 (2003), pp. 343-351. http://dx.doi.org/10.1002/col.10178

(17) Miller, A. Z.; Leal, N.; Laiz, L.; Rogerio-Candelera, M. A.; Silva, R. J. C.; Dionisio, A.; Macedo, M. F.; Saiz-Jiménez, C.: "Primary bioreceptivity of limestones used in Southern Europe monuments", in B. J. Smith, M. Gómez-Heras, H. A. Viles, J. Cassar (eds.), Limestone in the Built Environment: Present Day Challenges for the Preservation of the Past (2010), Geological Society Special Publications, London, vol. 331, pp. 79-92.

(18) ISO 4287:1984. Surface roughness-terminology: Part 1. Surface and its parameters. International Organization for Standardization. (19) Mark, R.; Billo, E.: "A stitch in time: Digital panoramas and mosaics", in Freers, S. M. (ed.), American Indian Rock Art, vol. 25 (1999), pp. 155-168.

(20) Sezgin, M.; Sankur, B.: "Survey over image thresholding techniques and quantitative performance evaluation", J. Electron. Imaging, vol. 13 (2004), pp. 146-165. http://dx.doi.org/10.1117/1.1631315

(21) Roeselers, G.; Zippel, B.; Staal, M.; Van Loosdrecht, M.; Muyzer, G.: "On the reproducibility of microcosm experiments —Different community composition in parallel phototrophic biofilm microcosms", FEMS Microbiol. Ecol., vol. 58 (2006), pp. 169-178. http://dx.doi. org/10.1111/j.1574-6941.2006.00172.x

(22) Donlan, R. M.: "Biofilms: microbial life on surfaces", Emerg. Infect. Dis., vol. 8 (2002), pp. 881-890. http://dx.doi.org/10.3201/eid0809.020063

(23) Morton, L. H. G.; Greenway, D. L. A.; Gaylarde, C. C.; Surman, S. B.: "Consideration of some implications of the resistance of biofilms to biocides", Int Biodet. Biodegr., vol. 41 (1998), pp. 247-259. 